\title{
PROCEEDINGS of the
}

Society of Antiquaries of Scotland

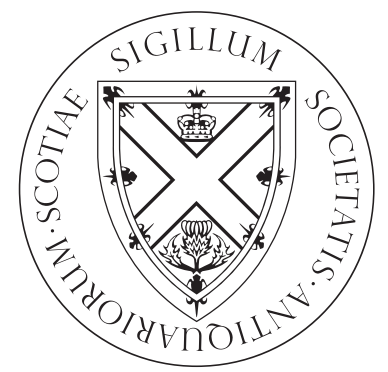

Volume 149

(2019-20) 
This volume has been printed on acid-free paper.

Requests for permission to reproduce material from the Proceedings should be made via the Society website: https://www.socantscot.org/publications/copyrightpermissions/

Copyright in the Proceedings rests with the Society and the individual authors. It is permitted, without the need for specific authorisation or payment of a fee, to photocopy:

i. single copies of individual papers or sections of the Proceedings for the private use of an individual;

ii. single copies of individual papers or sections of the Proceedings for library reserve or short-term loan use;

iii. multiple copies of individual papers or sections of the Proceedings for teaching use, provided that such copies are taken for a non-profit-making institution for educational use within that institution only.

The consent does not extend to copying for general distribution, advertising or promotional purposes, the creation of new collective works or resale.

The Society of Antiquaries of Scotland is a registered Scottish charity No. SC010440

ISSN 0081-1564

E-ISSN 2056-743X

Typeset by Waverley Typesetters, Warham, Norfolk

Manufactured in Great Britain by Bell \& Bain Ltd, Glasgow

Published December 2020 


\title{
Table of Contents
}

\author{
v LIST OF ABBREVIATIONS \\ vii EDITORIAL ADVISORY BOARD \\ ix COUNCIL \\ xi PATRON AND HONORARY FELLOWS \\ xiii LAWS OF THE SOCIETY OF ANTIQUARIES OF SCOTLAND \\ OBITUARY \\ 1 Dr Harry Aubrey Woodruff Burl \\ Alex Gibson
}

ARTICLES AND REPORTS

7 Clanranald's inland Uist waterway: fact or fiction?

\section{Stewart Angus}

25 Torwood Broch: the reassessment of a Complex Atlantic Roundhouse near Falkirk Murray Cook, Graeme Cavers, Gemma Cruickshanks, Gemma Hudson, Fraser Hunter and Fiona McGibbon

51 The Earl of Buchan's political landscape at Dryburgh, 1786-1829

\section{Aonghus MacKechnie}

83 Survey and excavation at an Iron Age enclosure complex on Turin Hill and environs

James O'Driscoll and Gordon Noble

115 'Tuesday Morning', the schoolboy and Mann: early medieval burials at Holm Park near Ballantrae, Ayrshire, Scotland

Nyree Finlay, Paul Duffy, Dene Wright, Adrián Maldonado and

Ruby Cerón-Carrasco

131 La Roundele, Berwick-upon-Tweed: a lost southern broch?

Catherine Kent

145 Dun Ara: a Norse-period 'harbour' in Mull?

James Petre 
165 New dates for enclosed sites in north-east Scotland: results of excavations by the Northern Picts project

Gordon Noble, James O’Driscoll, Cathy MacIver, Edouard Masson-MacLean and Oskar Sveinbjarnarson

197 John Ritchie Findlay (1824-98): architectural patron and philanthropist

\section{Clarisse Godard Desmarest}

This paper was awarded the R B K Stevenson Award

221 Old Kinord, Aberdeenshire: survey and excavation at an Iron Age settlement on Deeside Tanja Romankiewicz, Richard Bradley and Amanda Clarke

249 Protecting a Pict?: further thoughts on the inscribed silver chape from St Ninian's Isle, Shetland

\section{Katherine Forsyth}

277 Castle Camus, Isle of Skye: buildings, materials and radiocarbon analysis in the borderlands of medieval Sleat

Mark Thacker

303 INDEX 


\section{List of abbreviations commonly used in the Proceedings}

ADS Archaeology Data Service

AIA Association for Industrial Archaeology

ALGAO Association of Local Government Archaeological Officers

BAR British Archaeological Reports

CBA Council for British Archaeology

CIfA Chartered Institute for Archaeologists

CSA Council for Scottish Archaeology (now Archaeology Scotland)

DES Discovery and Excavation in Scotland

DSR Data Structure Report

HER Historic Environment Record

HES Historic Environment Scotland

HMSO Her Majesty's Stationery Office

NMR National Monuments Record*

NMRS National Monuments Record of Scotland $\dagger$

NMS National Museums Scotland

OS Ordnance Survey

OSA Old Statistical Account 1791-99

RCAHMS Royal Commission on the Ancient and Historical Monuments of Scotland

SAIR Scottish Archaeological Internet Reports

SMR Sites and monuments record

* Now English Heritage Archive

$\dagger$ Now National Record of the Historic Environment 


\section{Editorial Advisory Board for the Proceedings vol 149}

Professor David Breeze, OBE BA PhD HonDLitt FSA FRSE HonFSAScot HonMCIfA

Mike Church, BSc(Hons) PhD FSAScot

Professor John Collis, BA MA PhD FSA FSAScot MCIfA

Professor Gordon CoOK, BA PhD FSAScot

Vicki Cummings, PhD FSA FSAScot MCIfA

Professor Jane Downes, BA(Hons) PhD FSAScot MCIfA

Professor Steve Driscoll, BA MSc PhD FSA FSAScot

Professor Kevin Edwards, MA PhD FRGS CGeog FSA FRSE FSAScot

Professor William Gillies, BA MA FSAScot

AnNa Groundwater, PhD FRHistS FSAScot

Strat Halliday, BSc FSAScot

Professor Dennis Harding, MA DPhil FRSE FSAScot

Fraser Hunter, BSc PhD FSA FSAScot

HeATHER JAMES, BA PhD FSAScot MCIfA

BRENDAN O'CONNOR, BA DPhil FSA FSAScot

Professor Richard Oram, MA PhD FSA FSAScot

Professor IAN RALSTON, OBE MA PhD DLitt FSA FRSE FSAScot MCIfA MAE

Ronan ToOLIS, MA(Hons) FSAScot MCIfA

Caroline Wickham-Jones, MA MSocSci FSA FSAScot MCIfA

Managing Editor

Adela Rauchova, MA

Indexer

Susan Vaughan

Publications Production Manager

LAWRIE LAW

Office Managers

JACQUi Clabby, BA

KaYleigh Darlington

Publications Officers

Charlotte Whiting, MA (Hons)

Kate Bailey, MA(Hons) MSc 


\section{Society of Antiquaries of Scotland Council from 30 November 2018}

(DATE OF ELECTION AND RETIREMENT IN BRACKETS)

President

David CALDWEll, MA PhD FSA (elected 1 December 2014, re-elected 30 November 2017)

Vice-President

Barry G Ferguson, MA(Hons) (30 November 2015, appointed Vice-President 19 December 2016, re-elected 30 November 2018)

Treasurer

Stephen CARTER, BSc PhD MCIfA (re-elected 30 November 2018)

\section{Councillors}

Dawn McLaren, MA(Hons) PhD MCIfA (30 November 2015, re-elected 30 November 2018)

Sharon Webb, BA(Hons) MPhil PhD (30 November 2015, re-elected 30 November 2018)

Hector MacQueEn, LLB(Hons) PhD FBA FRSE (elected 30 November 2017)

IAIN McDowaLl (elected 30 November 2017)

Mhairi Maxwell, PhD (elected 30 November 2017, resigned 18 March 2019)

Sally Foster, BA(Hons) PhD FSA MCIfA (elected 30 November 2018)

Deborah Lamb, MA(Cantab) PhD (co-opted 18 December 2017, elected 30 November 2018)

Co-opted Members of Council (date of co-option in brackets)

None

Ex Officio Members of Council

Chair of the Aberdeen and North-East Section

NeIl CurTis, MA MLitt AMA (elected 24 April 2018)

Representative of the National Museums Scotland

XerXes Mazda, PhD (appointed 29 August 2016) 


\section{Patron and Honorary Fellows of the Society of Antiquaries of Scotland}

\section{Patron}

Her Majesty The Queen

Honorary Fellows (HonFSAScot)

HRH Prince Charles, The Prince of Wales, The Duke of Rothesay

Dr Robert ANDERson, BSc MA DPhil FSA FRSE FRSChem

Mr C NeAl Ascherson

Professor Richard Bradley, MA FSA Fl Dr hc FBA MCIfA

Professor David J Breeze, OBE BA PhD FSA FrSE HonDLitt HonMCIfA

Professor Martin Carver, BSc Dip.Archaeol FSA

Professor John Coles, MA PhD ScD FSA FBA FIDhc FRSA HonMCIfA HonMRIA

Emeritus Professor Ted Cowan, MA FRSE

Dame Emeritus Professor Rosemary Cramp, DBE MA BLitt FSA FBA

Professor George Eogan, BA PhD DLitt LittD FSA MRIA

Emeritus Professor Richard Fawcett, OBE PhD FSA FRSE

Dr Isabel Henderson, OBE MA(Abdn) MA, PhD(Camb)

Ms Audrey Shore Henshall, OBE MA FSA

Professor Dr LeEndert Kooljmans

Professor Kristian Kristiansen, HonFSA HonMEAA

Emeritus Professor J V S Megaw, AM MA DLitt FAHA FSA MCIfA

Diana Murray, CBE MA FSA MCIfA

Professor Colin Renfrew (Lord Renfrew of Kaimsthorn), ScD FSA FBA

Dr Anna Ritchie, OBE BA PhD FSA

JANE RYDER, OBE MA WS FSA FRSE

Lisbeth Thoms, MBE BSc Dip.Archaeol

Emeritus Professor J Diderik van der WaAls, DLIT

Professor Dr W Groenman-van W Aateringe

Caroline Wickham-Jones, MA FSA MCIfA 


\section{The Society of Antiquaries of Scotland was founded 18 December 1780 and incorporated by Royal Charter 6 May 1783}

It is a registered Scottish Charity No. SC010440

\section{LAWS OF THE SOCIETY FROM 1 DECEMBER 2014}

1. The purpose of this Society shall be the study of the ANTIQUITIES AND HISTORY OF SCOTLAND, more especially by means of Archaeological Research.

2. The Society shall consist of Fellows and Honorary Fellows.

3. Candidates for admission as Fellows must sign the Form of Application prescribed by the Council, and must be sponsored by two Fellows. Admission shall be by ballot. In the case of candidates not able to obtain two sponsor Fellows, it shall be open to the Council after consideration of the circumstances and credentials of the candidate concerned, to waive the necessity for two sponsors from among the Fellowship.

4. Council shall cause the names of the Candidates and their Sponsors to be circulated to all Fellows at least ten days before the date of the meeting at which a ballot is to be held. Fellows may vote against any candidate by striking out the name from the list and returning the list to the Society before the meeting or placing the list in the Ballot Box before the meeting commences. Candidates receiving ten or more adverse votes will be balloted for individually at the meeting, and any candidate then receiving less than two-thirds of the votes shall not be admitted.

5. Honorary Fellows shall consist of persons eminent in any branch of antiquarian study, who must be recommended by the Council and elected in the same way as Fellows; they shall not be liable for any fee for admission or annual subscription. The number of Honorary Fellows shall not exceed 25 .

6. Before the name of a newly elected candidate is added to the list of Fellows, he or she shall pay to the funds of the Society an entrance fee and the current year's subscription as provided for by Law 7.

7. Rates of entrance fee and annual subscription shall be determined by the Council as required from time to time subject to the approval of the Society given at a General Meeting. The annual subscription shall become due on 1st July in each year for that year then beginning; and if any Fellow who has not compounded shall fail to pay the subscription for one year, due application having been made for payment, the Treasurer shall report the same to Council, by whose authority the name of the defaulter may be erased from the List of Fellows. Fellows whose membership has lapsed, and who wish to re-join the Society, may do so either (1) by payment of all arrears of subscription - in which case they shall receive the relative volumes of the Proceedings, if still available - or (2) on payment of the subscription for the current year and of the entrance fee.

8. Every Fellow not being in arrears of the annual subscription shall be entitled to receive the Proceedings of the Society in printed or electronic form from the date of election. 
9. None but Fellows shall vote or hold any office in the Society.

10. Subject to the Laws and to the control of the Society in General Meetings, the affairs of the Society shall be managed by a Council elected and appointed as hereinafter set forth. Eight members of the Council shall constitute a quorum, provided that number includes at least two Office-bearers and six elected members of Council.

11. The Council shall consist of at least eleven Fellows elected by the Society, the Chairman of the North-East Section ex officio, the Society representative of the National Museums Scotland (NMS) ex officio who is already a Fellow of the Society (nominated by the NMS Board of Trustees) and up to two co-opted persons appointed by the Council to fill a vacancy on the Council. The total number of members of the Council shall not exceed fifteen at any time.

12. The Office-bearers of the Council shall consist of a President, two Vice-Presidents and a Treasurer.

13. The President shall be elected for a period of up to three years and may stand for election as President for a second term, subject to Law 16 below. The Treasurer shall be elected for one year and, subject to Law 16 below, shall be eligible for re-election provided however that the term of office of the President and the Treasurer respectively may not exceed six years in total. The elections of the President and the Treasurer shall be by ballot at the Annual General Meetings upon a list issued by the Council for that purpose to the Fellows at least fourteen days before the meeting.

14. The Vice-Presidents shall be appointed by the Council from amongst the elected members of the Council. The Vice-Presidents shall be appointed for an initial term of up to three years and may be appointed for a further term of up to three years, subject to Law 16 below.

15. Elected members of the Council shall hold office as Council members for an initial term of up to three years. A retiring Member of the Council who has held office for one term shall be eligible for re-election as a member of the Council and, if so re-elected, shall hold office for a further term of up to three years. The election shall be by ballot at the Annual General Meeting upon a list issued by the Council for that purpose to the Fellows at least 14 days before the meeting.

16. A retiring member of the Council who has held office for two terms shall not be eligible for reelection as a member of the Council unless such re-election is as an Office-bearer of the Council, provided however that no person shall be eligible for re-election as a member of the Council in any circumstances if such re-election would result in that person's period of membership of the Council in any capacity exceeding nine years unless a period of at least two years has elapsed since the date of that person's previous retirement from the Council.

17. A co-opted member of the Council shall be eligible for election as a member of the Council in accordance with Law 15 at the next Annual General Meeting following their appointment as a co-opted member of the Council and shall vacate office at the conclusion of that Annual General Meeting if they are not elected as a member of the Council. Immediately following each Annual General Meeting, the Council may re-appoint under Law 11 any individual who, as a co-opted member of the Council, vacated office under this Law at the conclusion of an Annual General Meeting; the Council may alternatively appoint someone in their place or resolve not to fill the vacancy.

18. Vacancies among the elected members of Council, the President and the Treasurer occurring by completion of term of office, by resignation, death or otherwise shall be filled by election at the 
Annual General Meeting, or, in the case of the Treasurer, at any earlier meeting of the Society as decided by the Council.

19. The Council may appoint committees or individuals to advise on the Society's business. Individuals who are not Fellows and Fellows who are not members of the Council shall be eligible for these duties.

20. The Annual General Meeting of the Society shall take place on St Andrew's Day, 30th November, or on the preceding or the following day if the 30th be a Sunday. The business of the Annual General Meeting shall be notified to Fellows at least fourteen days before the day of the meeting.

21. The Council shall have the power to call Extraordinary General Meetings when they see cause. At least fourteen days' notice of an Extraordinary General Meeting shall be given to Fellows.

22. Meetings of the Society, termed Ordinary Meetings, shall be held on such dates and at such places as may be determined by the Council. A minimum of six meetings, in addition to the Annual General Meeting provided for in Law 20, shall be held in each year.

23. Every proposal for altering the Laws must be made through the Council, which shall cause intimation thereof to be made to all the Fellows at least thirty days before the General Meeting at which it is to be determined on. 